\title{
PAINEL DE DIREITO PENAL E PROCESSUAL PENAL EM HOMENAGEM AO PROF. LAERTES DE MACEDO MUNHOZ — CARTA DE CURITIBA
}

Foi realizado em Curitiba, no período de $1 .^{\circ}$ a 3 de dezembro de 1977, no Salão Nobre da Faculdade de Direito da Universidade Federal do Paraná, o Painel de Direito Penal e Processual Penal, em homenagem ao saudoso professor e penalista Professor Laertes de Macedo Munhoz.

O tema geral do conclave esteve subordinado ao "Direito Penal e Processual Penal e o Futuro".

O painel, realização do Departamento de Direito Penal e Processual Penal da UFPr., Instituto dos Advogados do Paraná, Ordem dos Advogados do Brasil, Seção do Paraná e Instituto Brasileiro de Ciências Penais, Seção do Paraná, alcançou pleno êxito, tendo sido observado, durante os seus trabalhos, o seguinte programa:

\section{1. ${ }^{\circ}$ de dezembro de 1977}

09:00 horas Presidência: Prof. Fernando Andrade Oliveira.

Conferência: Prof. Alcides Munhoz Netto

Sub-tema: $O$ Direito Penal Liberal

15:00 horas Presidência: Prof. Athos Moraes de Castro Vellozo Conferência: Prof| Antonio Acir Breda

\section{2 de dezembro de 1977}

09:00 horas Presidência: Prof. Eduardo Rocha Virmond.

Conferência: Prof. Ariosvaldo Campos Pires

Sub-tema: $O$ Direito Penal e o Crescimento da Criminalidade.

15:00 horas Presidência: Prof. Ildefonso Marques

Conferência: Prof. Damásio Evangelista de Jesus.

Sub-tema: $O$ Direito Penal e as Garantias Constitucionais. 


\section{3 de dezembro de 1977}

09:00 horas Presidência: Prof. Alcides Munhoz Netto.

Conferência: Prof. Miguel Reale Junior.

Sub-tema: O Estado Contemporâneo e o Direito Penal.

11:00 horas Votação das Conclusões.

Os seus participantes foram os seguintes:

\section{Membros Natos:}

Professores: Francisco Accioly Rodrigues da Costa Filho; Ariosvaldo Campos Pires; Damásio Evangelista de Jesus; Plínio de Oliveira Correa; Miguel Reale Junior; Renê Ariel Dotti; Idefonso Marques; Athos Moraes de Castro Vellozo; Alcides Munhoz Netto; Fernando Andrade Oliveira; Eduardo Rocha Virmond; Luis Gastão de Alencar Franco de Carvalho; Fernando Newton Bittencourt Fowler; Luiz Alberto Machado; Luiz Chemin Guimarães; Antonio Acir Breda; Oto Luiz Sponholz; Francisco Accioly Rodrigues da Costa Neto; Dálio Zippin Filho; Rolf Koerner e Sônia Castro.

2. Membros Inscritos: advogados, professores, magistrados e membros do Ministério Público, devidamente inscritos, com direito a voz e voto.

3. Membros Assistentes: os presentes às conferências e sessões de debates, não portadores do grau de bacharel em direito, mas devidamente inscritos, com direito a voz.

A.pós as conferências foram realizados debates e apresentadas comunicações, indicações e moções, orais ou escritas.

Houve debates, com duração de uma hora (prorrogável por mais trinta minutos, a critério do Presidente), com a votação das conclusões parciais.

Tiveram direito a voz e voto, em plenário, os membros nalos e os membros inscritos. Os membros assistentes somente participaram dos debates, antes do início das votações.

Cada sessão foi secretariada por um membro designado pela respectiva presidência.

As conclusões foram redigidas por um Relator Geral.

Aos membros natos, inscritos e assistentes foram fornecidos certificados de participação no Painel de Direito Penal e Processual Penal em Homenagem ao Professor LAERTES DE MACEDO MUNHOZ. 


\section{CARTA DE CURITIBA}

Os professores, magistrados, membros do Ministério Público, advogados e estudantes, membros natos, inscritos e assistentes do Painel de Direito Penal e Processual Penal em Homenagem ao Professor LAERTES DE MACEDO MUNHOZ, entendendo serem direitos humanos da personalidade a vida, a integridade física e da saúde, a honra, a liberdade física e de opinião, portanto indisponíveis para o seu titular e sacrais para o Estado, consideram que o direito penal e o direito processual penal, compromissados com o Estado de Direito, devem se fundamentar, entre outros, nos seguintes prircípios:

1. A legislação penal tem como finalidade primordial limitar o poder punitivo do Estado.

2. As sanções penais, pela gravidade de que se revestem, devem ficar reservadas para as condutas intoleráveis à livre realização da personalidade ética do homem.

3. O direito penal liberal é incompatível com a tipificação de condutas inspirada na preocupação de impor concep̧̧̃es morais ou de ajudar o destinatário da norma.

4. O direito penal deve ser escoimado das infrações para as quais a pena é desnecessária ou comprovadamente inútil.

5. A segurança nacional é o somatório da segurança de cada cidadão, quanto aos seus direitos humanos fundamentais. Consequentemente, a legislação sobre segurança nacional deve manter apenas as infrações realmente graves, excluindo as condutas de simples exposição de idéias filosóficas e ou políticas. De qualquer forma, a pena deve guardar proporcionalidade com a gravidade das infrações.

6. O direito penal liberal é incompatível com a pena fundamentada na periculosidade. A sanção penal só é justa quando imposta em relação à culpabilidade, entendida como a censura pessoal sobre quem tinha condições de abster-se da ação.

7. O direito penal não é responsável pelo combate à criminalidade. Compete-lhe apenas ofertar um elenco de penas que permita uma integração harmônica entre os seus fins e o direito individual de liberdade.

8. As exigências de funcionamento e eficiência do Poder Judiciário não podem prevalecer sobre os valores de justiça, igualdade e paz social. 
9. A busca, pelo Estado contemporâneo, de maior eficiência administrativa, atrav;s de crescente burocratização, deve compatibilizar as perspectivas e contribuições dos humanistas com as dos técnicos.

10. A independência do Poder Judiciário é condição irrenunciával à realização da Justiça penal.

11. A justa aplicação do direito penal só é possível através de julgamento presidido por autoridade jurisdicional independente e imparcial.

12. A lei processual que prejudique o direito de defesa, ou que desconsidere a garantia constitucional do contraditório, rão deve ser aplicada.

13. A detenção ou a prisão de qualquer pessoa deve ser precedida de controle jurisdicional. A prisão para averiguações é incompatível com os postulados democráticos do direito processual.

14. A prisão provisória só deve ser tolerada em casos excepcionais.

15. A pessoa acusada da prática de um delito, antes da sentença trânsita em julgado, deve ser presumida inocente. A presunção de inocência é um direito individual supra-constitucional.

16. O direito procesual penal democrático é incompatível com qualquer restrição ao remédio constitucional do habeas corpus.

Curitiba, dezembro de 1977. 